IRSTI 14.35

\author{
Gumarova Sh.B., Strautman L.E. \\ Senior lecturer, Al-Farabi Kazakh National University, \\ Kazakhstan, Almaty, e-mail: strat50@mail.ru

\section{MACHINE TRANSLATION IN TEACHING THE COURSE OF SCIENTIFIC TECHNICAL TRANSLATION}

In the modern world of computer technologies and machine translations the procedure of translation has changed dramatically. The environment in which the students are studying now is very different from the environment for which our textbooks are designated. Therefore the fact that machine translations have become an integral part of the translation procedure should be taken into account in the educational process in teaching the course of Scientific Technical Translation. In all the articles available in the Internet the problem of machine/computer translation is considered only in terms of mistakes in the computer translation and corrections made by professional human translators. In this article the authors focus on pluses and minuses of using computer translation in teaching the course of Scientific Technical Translation. The authors have shown that computer translation and comparison of different translations of the same text has a positive effect on the educational process, and gives the students an impetus for creative thinking and creative assessment of their results. However, the authors have revealed that such a simple way of getting a translated text without any efforts spent on searching individual words has a negative effect on learning new words. Therefore the authors recommend to intensify pre-translational and post-translational exercises focused on active lexis of the translated text.

Key words: course of scientific technical translation, computer translation, pre-translational and post-translational exercises.

Гумарова Ш.Б., Страутман А.Е.

әл-Фараби атындағы Қазақ ұлттық университетінің аға оқытушылары,

Қазақстан, Алматы қ., e-mail: strat50@mail.ru

Ғымыми-техникалық аударма курсын оқытудағы

компьютерлік аударма

Қазіргі заманда компьютерлік аудармада аудару процедурасы күрт өзгерді. Студенттердің оқып жатқан орталары біздің оқулықтарымыздан өте ерекшеленеді. Өйткені, компьютерлік аудармалар аударма процедурасының ажырамас бөлігі болып саналады. Бұларды ғылымитехникалық аударма курстарын оқыту кезінде ерекше ескерген жөн. Интернеттегі барлық мақалаларда компьютерлік аударма мәселесі компьютерлік аударма қателіктері мен кәсіби аудармашылардың түзетулерімен ғана қарастырылады. Бұл мақалада авторлар ғылыми және техникалық аударма курстарын оқытуда компьютерлік аудармаларды пайдаланудың артықшылықтары мен кемшіліктеріне назар аударады. Авторлар компьютерлік аудару және сол мәтіннің әр түрлі аудармаларын салыстыру, оқу үдерісіне оң әсерін тигізді. Студенттердің шығармашылық ойлауына және олардың нәтижелерін шығармашылық тұрғылан бағалауға ынталандырады. Бұл мақалада осындай қарапайым тәсілмен аударылған текстер жаңа сөздерді үйренуге кері әсерін тигізетінін баса айтады. Сондықтан, авторлар аударылғанға дейінгі және аударылғаннан кейінгі жаттығуларға ерекше мән беруді ұсынады.

Түйін сөздер: ғылыми-техникалық аударма курсы, компьютерлік аударма, алдын ала аудару және аудармадан кейінгі жаттығулар. 


\author{
Гумарова Ш.Б., Страутман А.Е. \\ ст. преподаватели Казахского национального университета им. аль-Фараби, \\ Казахстан, г. Алматы, e-mail: strat50@mail.ru \\ Компьютерный перевод \\ в преподавании курса научно-технического перевода
}

\begin{abstract}
В современном мире компьютерных технологий и машинных переводов процедура перевода резко изменилась. Среда, в которой сейчас учатся студенты, сильно отличается от среды, Аля которой предназначены наши учебники. Поэтому тот факт, что машинные переводы стали неотъемлемой частью процедуры перевода, следует учитывать в учебном процессе при преподавании курса научно-технического перевода. Во всех статьях, доступных в Интернете, проблема машинного/компьютерного перевода рассматривается только с точки зрения ошибок в компьютерном переводе и исправлений, сделанных профессиональными переводчиками. В Аанной статье авторы акцентируют внимание на плюсах и минусах использования компьютерного перевода в преподавании курса научно-технического перевода. Авторы показали, что компьютерный перевод и сравнение разных переводов одного и того же текста положительно влияют на учебный процесс и дают учащимся стимул к творческому мышлению и творческой оценке их результатов. ОАнако авторы выявили, что такой простой способ получения переведенного текста без каких-либо усилий, затрачиваемых на поиск отдельных слов, отрицательно влияет на изучение новых слов. Поэтому авторы рекомендуют более активно использовать пред-переводные и пост-переводные упражнения, ориентированные на активную мексику переведенного текста.
\end{abstract}

Ключевые слова: курс научно-технического перевода, компьютерный перевод, предпереводные и пост-переводные упражнения.

\section{Introduction}

In the modern world of computer technologies and machine translations the procedure of translation has changed dramatically. It has little in common with the procedure well-known to the translators of the older generation. The translator does not need to use dozens of dictionaries in search for a word or word collocation, which was too time-consuming and low-efficient. Nowadays every student knows how to use the computer to translate the text. Therefore the environment in which the students are studying now is very different from the environment for which our textbooks are designated. In all the articles available in the Internet the problem of machine/computer translation is considered only in terms of mistakes in the computer translation and corrections made by human professional translators. Claude Piron writes that machine translation automates the easier part of a translator's job but the harder part involving resolution of grammatical and lexical ambiguities remains to the human translator. Unedited machine translation is available through tools on the Internet such as Google Translate, Babel Fish, Babylon, and StarDict. These produce rough translations that «give the gist» of the source text (Claude Piron. http://ayatranslator.blogspot.com/2017/11. htpm). Though the article was written not long ago, it can be argued that now machine translation is not a «gist», but the text that roughly reflects the context of the source text. An especially challenging is machine translation for the pair of the languages with absolutely different structures. For example, in the English-Arabic translation the researcher found 366 language errors in 100 sentences. The errors were subdivided into syntactic errors (55 errors), grammatical errors (174 errors) and semantic errors (137 errors) (Ahmad Muhammed Al-Samawi. http://awej.org/images/AllIssues/ Specialissues/ Translation3/17.pdf). A similar conclusion was made by Joke Daems in his research on post-editing effort after machine translation https://www.frontiersin.org/articles/ 10.3389/fpsyg.2017.01282/ full).In the article he stated that the grammar and syntax category was the most common error category in MT output. In order to achieve a meaningful and accurate translation Grace Oresile (https:// doi.org/10.3389/fpsyg.2017.01282) recommends to check that no information has been accidentally added or omitted and to use as much of the raw MT output as possible. In the group of EnglishRussian translation the main attention was also paid on the mistakes. Thus, in the article (Krasnova.URL https://moluch.ru/ archive/89/18290/) the main sources of mistakes were classified as grammar, syntactic mistakes and word conjunction and polysemy. Pelikovsky writes that in machine translation the sentence in the source language is subdivided into easily translatable elements and a 
statement with the same structure is created in the target language (Pelikovsky. http://rusnauka.doc. htm).

However, the impact of computer translation on teaching the course of Technical Translation has not been considered. Therefore the fact that machine translations have become an integral part of the translation procedure should be taken into account in the educational process in teaching the course of Scientific Technical Translation.

\section{Experimental part}

The main task of the course Scientific Technical Translation is to teach students to translate authentic scientific and technical texts. Nowadays the students use computer translation in all the tasks they are given, sometimes even not understanding the content of the text without it. Now, when the students can find in the Internet and listen to the lectures of professors from top-ranked British and American universities, it becomes a strong motivation to learning the English language. However, it is necessary to prepare them, to teach them to reach the level, which enables the students to get the information from the Internet and to go on internships to the English-speaking countries. Very often, there is a big gap between the desire and skills required for its realization.

In this article we will consider pluses and minuses of the use of computer translation in teaching the course of Scientific Technical Translation. In all the articles available in the Internet the problem of machine/computer translation is considered only in terms of mistakes in the computer translation and corrections made by human professional translators, where it is shown that the machine does not see the details or accents, and corrected by a human translator. However, the impact of computer translation on teaching the course of Technical Translation has not been considered. First of all, it should be noted that for a professional translator the computer translation it is a leap forward, a revolution in translation, which has facilitated his/her work. There is no doubt, that it is a great plus. Now let us consider pluses and minuses it gives to the teaching process. On the one hand, and it is quite natural, it has a positive effect on reading and understanding texts on specialty. On the other hand, it has a negative impact on the students' vocabulary. Students stop learning words, they know that they can find the required translation not knowing individual words. The same result is observed with grammar exercises when the students find the rule and blindly copy it.

At first, let us compare different computer translators. We will consider three most popular computer translators used in translation of scientific texts Goggle, Yandex and Prompt and try to translate extracts from the textbooks used in the course of Scientific Technical Translation. We have already mentioned that due to the limited number of hours we mainly practice translation into a native language, only in the advanced groups we practice translation into English. It is interesting for the students to compare different variants of translation of the same text and this is an impetus for creative thinking.

Let us consider several examples:

\begin{tabular}{|c|c|c|c|}
\hline Original text & $\begin{array}{c}\text { Prompt } \\
\text { (https://www.translate.ru/) }\end{array}$ & $\begin{array}{c}\text { Yandex } \\
\text { (https://translate.yandex.fr/) }\end{array}$ & $\begin{array}{c}\text { Google } \\
\text { (https://translate.google.com/) }\end{array}$ \\
\hline $\begin{array}{l}\text { The kinetic energy of the } \\
\text { emitted photoelectron is } \\
\text { exactly equal to the amount of } \\
\text { energy holding the electron to } \\
\text { the nucleus subtracted from } \\
\text { the energy of the absorbed } \\
\text { photon. }\end{array}$ & $\begin{array}{l}\text { Кинетическая энергия } \\
\text { испускаемого фотоэлектрона } \\
\text { точно равна на сумму } \\
\text { энергии, держащей электрон } \\
\text { к ядру, вычтенному из } \\
\text { энергии поглощенного } \\
\text { фотона. }\end{array}$ & $\begin{array}{l}\text { Кинетическая энергия } \\
\text { испускаемого фотоэлектрона } \\
\text { в точности равна количеству } \\
\text { энергии, удерживающей } \\
\text { электрон в ядре, вычитаемой } \\
\text { из энергии поглощенного } \\
\text { фотона. }\end{array}$ & $\begin{array}{l}\text { Кинетическая энергия } \\
\text { испускаемого фотоэлектрона } \\
\text { в точности равна количеству } \\
\text { энергии, удерживаюеей } \\
\text { электрон в ядре, вычтенной } \\
\text { из энергии поглощенного } \\
\text { фотона. }\end{array}$ \\
\hline
\end{tabular}

It should be noted that just three-four years ago students did not use computer translation as it was even difficult to understand what the text was about. The computer translators have improved dramatically over the last three years, and now it is widely used. From this example we see that Prompt still makes a lot of mistakes, whereas Yandex and Google give practically excellent translations. 
Let us consider another example.

Einstein continued to extend his theories around the interaction of photons and atomic particles, going so far as to hypothesize those photons could have momentum, also a particle property, even though they had no mass (AplusPhysics.https://www.amazon.com//dp/ 0983563306).

\begin{tabular}{|c|c|c|}
\hline Prompt & Yandex & Google \\
\hline $\begin{array}{l}\text { Эйнштейн продолжал расширять } \\
\text { свои теории вокруг взаимодействия } \\
\text { фотонов и атомных частиц, } и д я, \\
\text { насколько выдвинуть гипотезу, что у } \\
\text { тех фотонов мог быть импульс, также } \\
\text { собственность частицы, даже при том, } \\
\text { что у них не было массы. }\end{array}$ & $\begin{array}{l}\text { Эйнштейн продолжал распространять } \\
\text { свои теории на взаимодействие } \\
\text { фотонов и атомных частиц, вьlдвигая } \\
\text { гипотезу, что эти фотоны могут иметь } \\
\text { импульс, а также свойство частиц, } \\
\text { даже если они не имеют массы. }\end{array}$ & $\begin{array}{l}\text { Эйнштейн продолжал расширять свои } \\
\text { теории вокруг взаимодействия фотонов } \\
\text { и атомных частиц, заходя настолько } \\
\text { далеко, что выдвигал гипотезу, что эти } \\
\text { фотоны могут иметь импульс, а также } \\
\text { свойство частиц, даже если они не } \\
\text { имеют массы. }\end{array}$ \\
\hline
\end{tabular}

In this sentence we see that Prompt incorrectly chose the translation of the word «property», which has the meaning «собственность» but not in this context. This sentence is better translated by Yandex, especially impressive is the finding «вы гая гипотезу» instead of «заходя настолько далеко» in Google translation, not to mention «идя, насколько выдвинуть гипотезу», suggested by Prompt.

Let us consider a more difficult example.

\begin{tabular}{|c|c|c|c|}
\hline Original text & Prompt & Yandex & Google \\
\hline $\begin{array}{l}\text { Einstein proposed that the } \\
\text { electrons in the metal object } \\
\text { were held in an «energy } \\
\text { well,» and had to absorb at } \\
\text { least enough energy to pull } \\
\text { the electron out of the well in } \\
\text { order to emit a photoelectron. } \\
\text { The electrons in the metal } \\
\text { would not be released unless } \\
\text { they absorbed a single photon } \\
\text { with that minimum amount } \\
\text { of energy, known as the work } \\
\text { function of the metal [8]. }\end{array}$ & $\begin{array}{l}\text { Эйнштейн предложил, } \\
\text { чтобы электроны в } \\
\text { металлическом предмете } \\
\text { проводились в «энергии } \\
\text { хорошо» и должны были } \\
\text { поглотить, по крайней } \\
\text { мере, достаточно энергии } \\
\text { потянуть электрон из } \\
\text { хорошо, чтобы испустить } \\
\text { фотоэлектрон. Электроны } \\
\text { в металле не были бы } \\
\text { выпущены, если они не } \\
\text { поглотили единственный } \\
\text { фотон с тем минимальным } \\
\text { количеством энергии, } \\
\text { известной как функиия } \\
\text { работы металла. }\end{array}$ & $\begin{array}{l}\text { Эйнштейн предположил, } \\
\text { что электроны в } \\
\text { металлическом объекте } \\
\text { удерживаются в } \\
\text { «энергетической яме» } \\
\text { и должны поглощать по } \\
\text { крайней мере достаточно } \\
\text { энергии, чтобы вытащить } \\
\text { электрон из ямы, чтобы } \\
\text { испустить фотоэлектрон. } \\
\text { Электроны в металле не } \\
\text { высвобождались бы, если } \\
\text { бы они не поглощали } \\
\text { один фотон с таким } \\
\text { минимальным количеством } \\
\text { энергии, известным как } \\
\text { рабочая функиия металла. }\end{array}$ & $\begin{array}{l}\text { Эйнштейн предположил, } \\
\text { что электроны в } \\
\text { металлическом } \\
\text { объекте удерживались } \\
\text { в «энергетической } \\
\text { яме» и должны были } \\
\text { поглощать, по крайней } \\
\text { мере, достаточно энергии, } \\
\text { чтобы вытащить электрон } \\
\text { из ямы, чтобы излучать } \\
\text { фотоэлектрон. Электроны } \\
\text { в металле не будут } \\
\text { выпущены, если они не } \\
\text { поглотят единственный } \\
\text { фотон с этим минимальным } \\
\text { количеством энергии, } \\
\text { известным как работа } \\
\text { выхода металла. }\end{array}$ \\
\hline
\end{tabular}

Here we clearly see that Prompt made several rude mistakes. It will be a good exercise to ask students to explain the mistakes and to find the best variant of translation. The first thing is to consider the translation of «propose»: «предложил» and «предположил». There is a slight difference between these words, and we can use this example as well as many other similar examples, to show that in our mother tongue we see this difference whereas very often we do not see such a difference and explain to the students how important it is to learn to understand such mistakes. There is no doubt that they will remember a funny variant of translation of «energy well» as «энергии хорошо» in the Russian version and learn the correct variant «энергетическая яма». A very good example is different translations of the term «work function» of the metal as «функиия работы металла», «рабочая функичи металла» and «работа выхода металла». Here the correct variant is given by Google translation. The «work function» is a good example of term formed from the words widely used in general English. However, the students will have to use a dictionary and not only a dictionary but also their knowledge in physics to find the correct translation. On the above examples we see how the students can 
work comparing the translations of words and expressions.

\section{Results and discussion}

In order to activate the work of the students it is necessary to use more lexical exercises. We have to keep in mind that at least $90 \%$ of students will translate the text for their homework by computer. Therefore it is necessary to extend a complex of exercises which will make students learn words and grammar rules doing their home tasks and not just to use computer translation. That is why pre-translation and post-translation analysis of the text acquires more importance than they had in the time when machine translation was not accessible.

Pre-translational exercises include different types of lexical exercises. The exercises include choosing the correct meaning of each individual word in the conditions of polysemy. In the Russian-English translations the choice of the wrong word can either make the sentence sound «non-English» or may dramatically change the meaning. For example, so often used Russian expression, which can be find in every second textbook for students, «Контрольные вопросы» was translated as «Security questions», which is to be «Control questions».

As most English words have several meanings, the students translating the text have to consider several options, which help them to remember the words in the context. The students also have to determine the tense of the sentence, to use the right word order, to choose the correct pronouns and try to use proper articles. It means that the translation of even one sentence needs the use of several grammatical rules, and the student using the computer translation has to prove why this or that expression was used.

It is useful to begin learning how to find proper English words from filling in the gaps in English sentences. Our home-made textbooks usually do not have this type of exercisers. They either have no exercises on translation into English or give full Russian sentences with the task, "Translate into English using the lexis of the text». Undoubtedly, it is too difficult for unprepared students. And they use the Google translator, which is getting better every month. As a result, the students get the Russian and the English version, very often not knowing the meaning of the words.

We activate the students' vocabulary by giving the tasks with one or two unknown or similar terms, which are further used in the text (Strautman, 2017:48):

The task is to determine/define the change in tin entropy during crystallization.

The term altitude determines/defines a height over the sea level.

Velocity is a vector quantity/value.

The limiting quantity/value of speed on this motorway is $60 \mathrm{mph}$.

Both English verbs to determine and to define are translated into Russian as определить, which causes problems in the translation. The students are to be explained the difference in meaning on the examples, with proper translation of the words.

It is important for science students to use the terms quantity and value properly. To find out the meaning of the words it is necessary to use the special dictionary, whereas the Google translator will correctly give the word «величина» in Russian.

After doing several lexical and grammar exercises on the content of the text, the students may try to improve the computer translation. For example, after doing exercises on inversion, such as

Not only is $g$ the gravitational field strength, it is also the acceleration due to gravity.

Nothing can make the proton move faster than the speed of light.

The students will be able to explain the inverse word order in the sentence can the strong nuclear force take over.

Not until the two nuclei actually come in contact can the strong nuclear force take over. Только когда два ядра действительно вступят в контакт, сильная ядерная сила не вступит во владение.

The above sentence can be used as an example of translation of lexical and grammar structures. The students have to find grammar structures and to explain the translation.

Further we give examples of incorrect translations with our corrections. Here the students have to use not only the knowledge of grammar and lexis but also the knowledge of physics.

The incorrect translation makes the students find the correct version and explain the reason for the mistake. In this concrete case it is «to take over» and using ABBYY LINGVO we find 1) принимать (должность, обязанности) от другого, to take over a business - принимать (на себя) руководство 2) вступать во владение (вместо другого лица) 3) (take over from) наследовать (кому-л.) 4) перевозить; перевозить на другой берег 5) соединять (по телефону) 6) переносить на следующую строчку 7) захватить власть. 


\begin{tabular}{|c|c|c|}
\hline $\begin{array}{l}\text { As two nuclei approach each other, all } \\
\text { the protons in one nucleus repel all the } \\
\text { protons in the other. Not until the two } \\
\text { nuclei actually come in contact can the } \\
\text { strong nuclear force take over. }\end{array}$ & $\begin{array}{l}\text { Когда два ядра сближаются, все } \\
\text { протоны в одном ядре отталкивают все } \\
\text { протоны в другом. Только когда два } \\
\text { ядра действительно вступят в контакт, } \\
\text { сильная ядерная сила не вступит во } \\
\text { владение. }\end{array}$ & $\begin{array}{l}\text { Когда два ядра сближаются, все } \\
\text { протоны в одном ядре отталкивают все } \\
\text { протоны в другом. Только когда два } \\
\text { ядра действительно вступят в контакт, } \\
\text { начинает действовать сильная } \\
\text { ядерная сила. }\end{array}$ \\
\hline $\begin{array}{l}\text { The Pauli exclusion principle provides } \\
\text { an explanation for this exceptional } \\
\text { behavior- it says that as protons and } \\
\text { neutrons are fermions, they cannot exist } \\
\text { in exactly the same state. (Dan Fullerton. } \\
\text { Aplusphysics//https://www.youtube. com/ } \\
\text { user/FizziksGuy) }\end{array}$ & $\begin{array}{l}\text { Принцип исключения Паули дает } \\
\text { объяснение этому исключительному } \\
\text { поведению - он говорит, что, } \\
\text { поскольку протоны и нейтроны } \\
\text { являются фермионами, они не могут } \\
\text { существовать в одном и том же } \\
\text { состоянии. }\end{array}$ & $\begin{array}{l}\text { Принции запрета Паули дает } \\
\text { объяснение этому исключительному } \\
\text { поведению - он говорит, что, так } \\
\text { как протоны и нейтроны являются } \\
\text { фермионами, они не могут } \\
\text { существовать в одном и том же } \\
\text { состоянии. }\end{array}$ \\
\hline
\end{tabular}

Here the source of incorrect translation is incorrect wording but the meaning is understandable. From this example the students see the importance of correct formulation of what they want to say or write.

The article suggests some ideas related to usage of computer translation in the course of scientific translation. The authors show how at the time when almost $100 \%$ of students use computer translation make students study the translated text more deeply and not superficially as it is often done, how to understand the meaning of every word given by the computer.

\section{Conclusion}

It has been shown that machine translation and comparison of different translations of the same text gives the students an impetus for creative thinking and creative assessment of their results. However, such a simple way of getting a translated text without any efforts spent on searching individual words has a negative effect on learning new words, the students get worse in learning new words, which requires usage of additional pre-translational and post-translational exercises focused on active lexis of the translated text.

\section{Литература}

Claude Piron. What is machine translation.

Ahmad Muhammed Al-Samawi. Language Errors in Machine Translation of Encyclopedic Texts from English into Arabic: the case of Google Translate http://awej.org/images/AllIssues/Specialissues/Translation3/17.pdf

Joke Daems et al. Identifying the Machine Translation Error Types with the Greatest Impact on Post-editing Effort https://www. frontiersin.org/articles/ 10.3389/fpsyg.2017.01282/full

Grace Oresile. The Importance of Machine Translation Post-Editing and Its Application to Translation https://doi.org/10.3389/ fpsyg.2017.01282

Краснова Т. И., Ванюшин И. С. Machine translation error analysis // Молодой ученый. URL https://moluch.ru/archive/89/18290/

Pelikhovsky Yu. Problem of machine translation http://rusnauka. com/PNR_2006/Philologia/6-Pelikhovsky.doc.html

Prompt https://www.translate.ru/

Yandex.translate https://translate.yandex.fr/

Google.translate https://translate.google.com/

APlusPhysics: Your Guide to Regents Physics Essentials https://www.amazon. com/APlusPhysics-Guide-Regents-PhysicsEssentials/dp/0983563306

Dan Fullerton. Aplusphysics // https://www.youtube.com/user/FizziksGuy

Strautman L.E., Gumarova Sh.B. et al. English for Physicists. - Алматы, 2017 - 125c.

\section{References}

Ahmad Muhammed Al-Samawi. Language Errors in Machine Translation of Encyclopedic Texts from English into Arabic: the case of Google Translate http://awej.org/images/AllIssues/Specialissues/Translation3/17.pdf

APlusPhysics: Your Guide to Regents Physics Essentials https://www.amazon. com/APlusPhysics-Guide-Regents-PhysicsEssentials/dp/0983563306

Claude Piron. What is machine translation http://ayatranslator.blogspot.com /2017/11.htpm) 
Crasnova T.I., Vanyushin I.S. Machine translation error analysis. Molodoy uchenyi (Young scientist). URL https://moluch.ru/ archive/89/18290/

Dan Fullerton. Aplusphysics // https://www.youtube.com/user/FizziksGuy

Google.translate https://translate.google.com/

Grace Oresile. The Importance of Machine Translation Post-Editing and Its Application to Translation https://oi.org/10.3389/ fpsyg.2017.01282

Joke Daems et al. Identifying the Machine Translation Error Types with the Greatest Impact on Post-editing Effort https://www. frontiersin.org/articles/10.3389/fpsyg. 2017.01282/full

Pelikhovsky Yu. Problem of machine translation http://rusnauka.com/PNR_2006/ Philologia/6-Pelikhovsky.doc.html

Prompt. https://www.translate.ru/

Strautman L.E., Gumarova Sh.B. et al. (2017). English for Physicists. Almaty. 125 p.

Yandex.translate https://translate.yandex.fr/ 